\title{
High Performance Work Systems as an Enabling Structure for Self-Organized Learning Processes
}

\author{
http://dx.doi.org/10.3991/ijac.v5i4.2327 \\ Thomas Wallner, Martin Menrad \\ University of Applied Sciences Upper Austria, Steyr, Austria
}

\begin{abstract}
High Performance Work Systems (HPWSs) as a new way of organizing work in general and of production work in particular provide an environment, where selforganized learning processes are enabled and fostered. In an extensive research project in two major Austrian manufacturing companies we currently investigate the applicability and the effects of HPWS including issues of learning and knowledge management. In this contribution we present the results of the first phase of this project discussing early empirical findings of an exploratory nature.
\end{abstract}

Index Terms-High Performance Work Systems, knowledge management, self-organization, sharing expertise, team work

\section{INTRODUCTION}

European manufacturing companies face multiple challenges when maintaining production sites domestic despite high wages and high social and environmental standards. All around the world, the dynamic development in emerging economies is accompanied by a massive expansion of infrastructure and large-scale educational projects. "A pair of skilled hands" can nowadays be found anywhere in this world, and many companies move their manufacturing sites or outsource production to regions where labor costs per unit are the lowest. However, in a global environment companies have to cope with complexity and volatility and it is essential to be highly adaptable and innovative in order to be successful, which creates new opportunities which may outweigh the factor of high labor costs. In scientific and practical discussions about how companies can maintain or gain competitive advantage in the future and at the same time manage to keep production domestic, "high road"-strategies that focus on innovation, and in particular High Performance Work Systems (HPWSs) are considered to have great potential [1].

Another challenge in many European countries and in Austria as well results from demographic changes, indicating an ageing workforce on one hand and a scarce supply of new talent on the other. Both trends raise specific issues at the company level, which can be addressed in part by concepts of life-stage-oriented work organization. Productive Ageing is a widely used key term in this context. A critical question in this context is for example, how the valuable knowledge of retiring employees can be maintained for the company, respectively, how older employees can be included in continuous training efforts.

\section{What ARE High PERFORMANCE WORK Systems?}

In opposition to "Low Road" strategies which focus on cost leader-ship and standardization, HPWSs are assigned to "High Road" (to innovation) strategies. HPWSs focus on continuous reinvention processes of products and services integrating creativity, experience and implicit knowledge of employees at all levels. HPWSs comprise of particular management practices (high performance work practices - HPWPs), concerning the organization of work and the company itself, like selfmanaged teamwork, flat hierarchical structures, job rotation, performance related wages or workforce empowerment. As opposed to tayloristic principals, HPWSs lead to a fundamental reorientation in operational rationalization efforts resulting in a new and increased appreciation of human work. In this context, the aspects "self-control" and "self-organization" are of particular importance. HPWSs, which are also known as high commitment or high involvement organizations, realize a managerial approach that facilitates high performance of employees and thus illustrates the amended character of work and the options of work sharing and knowledge sharing in today's knowledge-based economy [2].

HPWSs fundamentally differentiate themselves from traditional hierarchical or bureaucratic approaches which are basically command- and control-oriented [3]. "The fundamental difference between the control-oriented approach and the involvement-oriented approach concerns, how work is organized and managed at the lowest level in an organization. Companies using the controloriented approach assume that work should be simplified, standardized and specialized and that supervision and pay incentives should be used to motivate individuals to perform their tasks well. In essence, the thinking and controlling part of work is separated from the doing of the work" [3].

According to Eileen Appelbaum's work individual practices (High Performance Work Practices - HPWPs) like self-organized teamwork, performance related pay etc. have to be distinguished. A key element to higher productivity and stronger financial performance lies in the systematic implementation of HPWPs throughout a company by means of reorganizing the entire work system and not only applying individual practices ('bundling of work practices') [4] [5] [6]. There is also evidence though that many firms still take a 'piecemeal approach' in using such work practices rather than trying to employ a more inno- 
TABLE I.

Characteristics OF “INNOVATIVE WORK POLICIES” [4]

\begin{tabular}{|c|c|c|}
\hline & $\begin{array}{c}\text { Innovative work policies } \\
\text { / HPWSs }\end{array}$ & $\begin{array}{l}\text { Taylorism and neo- } \\
\text { tayloristic concepts }\end{array}$ \\
\hline $\begin{array}{l}\text { Work } \\
\text { Organiza- } \\
\text { tion }\end{array}$ & $\begin{array}{l}\text { Extended Group work } \\
\text { (self-managed work- } \\
\text { teams, integration of tasks } \\
\text { and functions); flexible } \\
\text { standardization }\end{array}$ & $\begin{array}{l}\text { Enforced division of labour; } \\
\text { hierarchical structures; rigid } \\
\text { standardization }\end{array}$ \\
\hline $\begin{array}{l}\text { Process } \\
\text { Improve- } \\
\text { ment }\end{array}$ & $\begin{array}{l}\text { Close-to-process } \\
\text { involvement of } \\
\text { employees regarding } \\
\text { process design and } \\
\text { improvement }\end{array}$ & $\begin{array}{l}\text { Detached, expert-based, } \\
\text { centralized, selective } \\
\text { process design and } \\
\text { improvement activities }\end{array}$ \\
\hline $\begin{array}{l}\text { Company } \\
\text { Organiza- } \\
\quad \text { tion }\end{array}$ & $\begin{array}{l}\text { Process-oriented } \\
\text { decentralization; } \\
\text { reduction of hierarchical } \\
\text { structures }\end{array}$ & $\begin{array}{l}\text { Centralized, bureaucratic, } \\
\text { functions-oriented } \\
\text { organisation }\end{array}$ \\
\hline $\begin{array}{l}\text { Manage- } \\
\text { ment }\end{array}$ & $\begin{array}{l}\text { Extended competencies } \\
\text { for low-level } \\
\text { management; reduction of } \\
\text { hierarchical structures; } \\
\text { development-oriented } \\
\text { approach }\end{array}$ & $\begin{array}{l}\text { Hierarchical; command- } \\
\text { and-control oriented } \\
\text { management approach }\end{array}$ \\
\hline $\begin{array}{l}\text { Coordina- } \\
\text { tion } \\
\text { and Con- } \\
\text { trolling }\end{array}$ & $\begin{array}{l}\text { Process-oriented, } \\
\text { negotiated coordination } \\
\text { and controlling systems }\end{array}$ & $\begin{array}{l}\text { Top-down or target- } \\
\text { oriented coordination and } \\
\text { controlling systems }\end{array}$ \\
\hline $\begin{array}{l}\text { Wage } \\
\text { systems and } \\
\text { perform- } \\
\text { ance policies }\end{array}$ & $\begin{array}{l}\text { Broad mix of various } \\
\text { remuneration } \\
\text { components; integrated, } \\
\text { negotiated and regulated } \\
\text { wage and performance } \\
\text { policy }\end{array}$ & $\begin{array}{l}\text { Tayloristic-bureaucratic } \\
\text { concepts of performance } \\
\text { policies }\end{array}$ \\
\hline
\end{tabular}

vative way [7] thus narrowing the possible gain of such a systematic approach [8].

Self-managed teamwork, which is based on the principle of self-organization and integrates a wide range of divers tasks and functions is a key strategy of "Innovative work policies". However, there is more to HPWSs than various forms of teamwork, and research shows an interactive effect with other HPWPs. Other HPWPs will not develop their full potential without the effective implementation of group work; they will in turn positively affect group work when they are well-established [4].

So far, HPWSs have primarily been applied and studied in a context of industrial production work and there is ample empirical evidence about the impact of HPWSs in these environments with regards to higher productivity, stronger financial performance [4], increased organizational agility and innovativeness [9]. Empirical research has also shown that systematical implementation of HPWPs by means of reorganizing the entire work system and not only individual practices ('bundling of work practices') is a key element to achieve these positive effects ) [4] [6].

Little is known about the effects (and limits) of specific HPWPs on learning processes, knowledge transfer and knowledge preservation, nor about what explains the success of their application/implementation as to serve this purpose.

\section{THE CONTEXT OF OUR RESEARCH PROJECT}

Having started in 2010, we are currently conducting a combined research project in the Austrian manufacturing plant of a global player in the automotive industries (company A, approx. 2.000 employees) and at the Austrian production site of an international high tech company in the metal industries (company B, approx. 1.000 employees) to determine the impact of HPWSs on the adaptability of organizations to volatile environmental conditions such as turbulent markets. In this context we have developed the concept of "Organizational agility" and we have introduced this to the scientific discussion in the field of Operations Management in July 2011 [10].

In company A the main scope is the scientific accompaniment of the implementation of various HPWPs on the shop floor. We monitored the process of implementation, evaluated the effects and will again do the accompanying research, when the measures are rolled out on the entire shop floor, which will happen in 2012. Further activities include a complete reorganization of operational management towards flat hierarchies and innovative approaches of integrating relevant areas on the shop floor into process-oriented structures. Thus, various HPWPs are being implemented in a systematic way and the bigger part of the plant will be involved in this project; in total 1.200 employees will be included in the project.

In company $\mathrm{B}$ we evaluate already existing forms of HPWSs, which are there organized in a company-specific production system.

Within this framework we are investigating a variety of issues related to HPWS such as:

- Productive Ageing

- Knowledge Management

- Training and Education

- Human Resources Development

In addition we are also performing explorative research about the applicability of HPWSs in other areas besides production such as production logistics and R\&D departments.

We have set up a multistage research process that relies on a combination of various sociological data collection analysis and methods. We tie this selection to the requirements of the case study method associated with industrial sociology to make sure that we fully understand the differences between the social processes and the company context it is embedded into. We understand that this approach is especially applicable when researching and evaluating the implementation and the effects of new forms of labor organization.

In this process we also want to introduce a systems theory perspective in the scientific discussion. We assume that systems theory can provide the theoretical framework to explain how and why particular HPWPs and HPWSs in general work (and contribute to the innovativeness and adaptability of an organization) and help to formulate the guiding principles for a further development thereof. 


\section{HPWS AND SELF-ORGANIZED LEARNING PROCESSES}

With regard to self-organized teamwork we can already rely on a substantial number of expert interviews, group discussions and observations. Self-organized teamwork usually entails a communication structure, which was in our case composed of brief daily discussions of approximately 5-10 minutes and longer weekly meetings of approximately 20 minutes. Topics include work assignments and scheduling, quality problems, sick leaves, vacation planning, work place safety, assignments and scheduling, quality problems, sick leaves, vacation planning, work place safety etc.

Based on the respective exploratory evaluation of this previous research material we do have strong suggestions that the self-organizing dynamics induces and allows for substantial learning processes, which happen in addition to and go far beyond planned and/or mandatory events and programs.

HPWSs may serve as an organizational frame to set up all kinds of learning processes. In HPWSs employees can develop and deploy their competencies and creative potential, they are able to assume responsibility and engage in opportunities for analysis, problem solving and innovation, in which the working environment is a place of learning [10]. Some High Performance Work Practices may be more adequate to fit this purpose than others.

\section{INITIAL EMPIRICAL FINDINGS}

Based on the respective exploratory evaluation of this previous research material we can present some initial findings, which can serve as a starting point for a specific empirical validation.

In a first attempt to group and categorize our observations we distinguished three classes of learning processes which will be presented here in further detail and which may be of interest for future research:

- The general transfer of corrective knowledge including tacit knowledge.

- in the course of everyday work.

- Self-organized development of additional competencies, (where self-organization is a prerequisite).

- Partly self-organized learning processes within a defined organizational structure.

1) The general transfer of corrective knowledge (including tacit knowledge)

To follow our line of argument, a few words have to be said about the term „,corrective knowledge“ and our understanding of the term „tacit knowledge“. Tacit knowledge has been introduced into discussing real life economic matters (e.g. business administration) by way of trying to explain the (economic) success of Japanese enterprises in the early nineties [11] but also in Sweden and the USA [12]. The idea (despite of many misunderstandings and misapplications in Europe, which provoked discussions on generations of KM (Knowledge Management) goes back to Michael Polanyi's “The Tacit Dimension” [13]. But while Polanyi insisted that some kind of knowledge (best termed "implicit" knowledge just as "implicit" used in implicit definitions in mathematics) cannot be made explicit completely.

Allee writes "for Polanyi, tacit knowledge could never be made explicit, nor does it need to be.” On the other hand "in common usage, people refer to tacit knowledge as what is in people's heads, and to explicit knowledge as tacit knowledge that has been codified and communicated [14]." Polanyi's position is "that tacit knowledge sharing underlies any act of communication, in the form of unspoken commonalities [our emphasis] around very basic perceptions and human interaction [13].” According to Polanyi, Allee (ibd.) points out that when knowledge is shared "there is an articulated or explicit communication and an unspoken tacit communication going on at the same time [our emphasis].” This aspect is important for the discussion below [14].

As mentioned above and in contradistinction to Polanyi, people seem to have got to the idea that tacit knowledge by itself simply needs to be made explicit. This idea "arose from thinking of tacit knowledge as stored memory, experience, or content that simply hasn't been articulated.” According to Nonaka and Takeuchi, "tacit knowledge -which is embedded in people's experience - is socialized or shared through direct experience. That shared experience can be articulated into explicit concepts that can then be systematized into a knowledge system. Once systematized, that now-explicit knowledge can be learned by others and once again become embedded in experience as tacit knowledge [...].” (cf. SECI model by Nonaka and Takeuchi [11] ).

This means that tacit knowledge cannot be verbalized completely and therefore not transferred directly.

The approach by Nonaka and Takeuchi (cf. SECI model) concerns especially "tacit knowledge", which in Western primarily cognitive thinking was understood to be that part, which could be externalized more or less completely (for a thorough discussion of the difference between Western and Eastern conceptions of knowledge see the article “Stuff or Love?” by Andriessen [15] ) [11].

To cut a long discussion short, what remains to be seen is that the transfer of "knowledge" - be it tacit, implicit or other - (to explain economic success) and even more important the transfer of "expertise" cannot be reduced to "words".

There are many ways, techniques and approaches of KM to take care of tacit/implicit knowledge as an important competitive advantage, i.e. source of better products or customer-serving solutions, like communities of practice, dialogue techniques, value networks, storytelling (e.g. Brown and Duguid [16] ). All of them contain a strong element of practice in combination with dialogue, i.e. elements of feedback to change the corrective background knowledge of humans, who apply certain production rules, heuristics or well documented routines.

The main problem seems to be that one has to provide both, i.e. reliable rules as well as "corrective knowledge" (to be transferred or built up by practice - but not to be confused with „best practices“) about the limits of the application of those rules (in order to prevent mistakes). 
The theoretical framework for these considerations has been presented in a model-theoretic approach LIR (Language-Information-Reality) to Knowledge Management by Gatarik and Born [17]. On the obsession of previous research efforts on knowledge sharing with „best practices“ as the prime object of investigation and seeing knowledge sharing as the process of bridging performance variations between organizational subunits see Christenses p. 39. [18].

This is where new approaches in the organization of work come into the picture. HPWSs may serve as an organizational frame to set up all kinds of communication processes to support the dialogue mentioned above. Some High Performance Work Practices may be more adequate to fit this purpose than others.

As already stated, we do have already quite some empirical data with regards to self-organized teamwork.

Hence we can report, that in the course of team meetings, e.g. the following additional issues are conveyed, which are usually not completely verbalized or addressed in a training or introductory course and thus can be considered as an expression of both implicit and tacit knowledge built up by feedback/practice:

- A practical discussion of working procedures, production data and quality data biased according to the prevalent interpretative patterns.

- Concrete aspects of the dominant "value system" as an expression of the corporate culture (which needs to be "felt").

- „Soft“ criteria for the appraisal of a certain solution.

- Specific group norms.

- Personality traits and individual decision criteria of team members and superiors.

- Machine-specific performance deviations, which are not reflected in working procedures (think also of the real history of a machine).

- Process- and machine specific operating or handling instructions, which are not part of general working procedures.

- Issues of work load, capacity and fair distribution of work.

- Political and work council issues.

- Individual qualification and qualification needs.

From the various High Performance Work Practices two more seem to be in particular suitable to provide the interactive setting and the contextual orientation, where the transfer of tacit knowledge can happen successfully and efficiently.

- Employee Driven Process Improvement.

- Job Rotation (including the interactive exchange about machine characteristics, process problems etc.)

While the former - like teamwork - usually involves group discussions (in need of dialogue and facilitators) of up to 12 employees, the latter involve mostly one-to-one communication.
However, all of three practices mentioned so far show characteristics of:

- Intensive topic-centered interaction.

- Specific instructions and / or hints with regards to experience based expert knowledge.

- referencing to an otherwise not explicitly expressed dominant corporate value system.

- including information about the social environment and significant individuals.

2) Self-organized acquisition of additional individual competencies

In the interviews, one manager reported about a - in terms of age - diverse team operating a range of older and newer machines. The older employees used to operate the old machines, having the knowledge and experience to cope with the particularities of the equipment, the younger ones used to operate the new machines, having the expertise to manage the digital control unit. Over a long period of time (several years) any attempts by the management to persuade the employees to expand their capabilities in order to be able to operate all machines in this channel section failed. The workers simply refused to respond to respective schedules and training efforts. However, after the introduction of self-organized teamwork the group started without further encouragement to explore the possibilities to include all employees and all machinery in job rotation arrangements by it-self.

This is a beautiful example how the practice Selfmanaged Work Teams (SMWT) in particular is aligning individual motivation with organizational objectives [19].

Usually, the implementation of HPWS involves training programs to allow the employees to acquire the necessary skills for autonomous decision making within the range of empowerment. In our case, empowerment for autonomous decision making was explicitly a prerequisite to induce the reported learning processes being in perfect accordance with current motivation theories, where autonomy and the quest for mastery have been identified as strong motivational drivers [20].

We have not investigated the motivational situation on the individual level in detail. However we do see here a promising field for further research.

3) Partly self-organized learning processes within a defined organizational structure.

This refers to the communication and spreading of best practices and their eventual implementation as a standard procedure or working instruction in the the related documentation of the Quality Management System.

In Company B the organizational and temporal structure of SMWT and the supportive framework are also employed to ensure the communication of deviations or quality problems, the respective problem solving activities and the corresponding solutions and other outputs of the continuous improvement process. This is common practice in many companies.

What is of particular interest in this organization, is the fact, that a rather open and fluid structure is used to assign 
the tasks and discuss and check the suggested ideas and solutions involving employees on all levels in the problem solving process.

For example: For an identified problem a „caretaker“ (in German: „Kümmerer“) is assigned; who the caretaker is, is completely open and not decided on the basis of a predefined organizational responsibility but on the simple question: Who is qualified best to solve this problem? The answer may be and quite often is: The one, who reported the deviation or the problem. He or she knows what he or she is talking about and obviously has a problem with it.

Another example is the check of an idea or a solution and the release of it for publishing in the global QualityWiki. Unlike earlier, when this was an expert's task, and the new standard operating procedure (work instruction) was simply communicated to and counter-signed by the employees, this is now done in a group discussion, where employees can participate on a voluntary base.

The elaborate solution or idea is presented by the caretaker; he or she has to explain the means and ends and to defend the solution. This leads reportedly to additional suggestions for improvement and increased acceptance of the new standard.

\section{PRACTICAL IMPLICATIONS AND CONCLUSION}

Concerning the Knowledge Management aspect of HPWS we have finished the first phase covering additional literature research and interpreting initial empirical findings to approach the subject in an exploratory way. Our preliminary conclusion is, that the application of specific HPWPs allow for and foster learning processes which otherwise would remain by and large submerged. Thus we conclude, that HPWS can be considered as an enabling structure for self-organized learning processes - a statement, which remains to be validated on a broader empirical base in our future research efforts.

Another interesting question will be how selforganized learning processes can be included in structured training and education programs. Furthermore the methodical integration of HPWS in general in corporate Knowledge Management and human resource and organization development strategies still has to be accomplished.

\section{A CLOSING REMARK ON THE SYSTEMS THEORY APPROACH}

HPWSs have been discussed in the fields of labor economics, industrial relations, (industrial) sociology, organizational behavior, strategic HRM (Human Resource Management) and operations management. However, in our literature reviews we have come across only a few specific references to a systems theory approach so far, although systems theory (in particular the complex adaptive systems perspective) might contribute fruitful insights into the underlying principles and structural conditions of HPWSs.

In various contributions van Einjatten (e.g. [21] [22]) focused on the complexity perspective and referring to the notion of Complex Adaptive Systems to investigate organizational issues in general and work organization in particular.

From the field of general systems theory Michel SaintGermain has linked HPWSs to the nature of open systems:

"[T]he individual as an open system is respected in such organizations. He/She is able to transform data into useful decision-making information. There is margin for creativity and autonomy and above all, the decisionmaking process allows opportunities for a 'locus of control' at the individual level” [23].

We argue, that systems theory can provide the theoretical framework to explain how and why particular HPWPs and HPWSs in general work (and contribute to the innovativeness and adaptability of an organization) and help to formulate the guiding principles for a further development thereof. One central concept in this respect is empowerment, which can be understood from the systems sciences perspective as the capability for self-organization and on the other hand as providing the structural means to allow for self-organization from an organization theory perspective in general and from the High Performance Work Systems approach in particular.

\section{REFERENCES}

[1] H. Nolte, and S. Haschen, "High Performance Work Systems: Overview and Discussion,” WiW-Online.de, Hamburg, 2010, http://www.odww.net/artikel.php?id=475, accessed 05.10.2011.

[2] P. Brödner, "The Future of Work in a Knowledge-Based Economy,” in ICT/CIREM Int. Seminar on "Economy and Work in the Knowledge Society”, Barcelona 24-25 February 2000.

[3] E. E. Lawler, "The ultimate advantage. Creating the highinvolvement organization,” 1. Ed., Jossey-Bass (A Joint publication in the Jossey-Bass management series and the JossyBass social and behavioural science series), San Francisco, 1992.

[4] M. Kuhlmann, H.J. Sperling, and S. Balzert, "Konzepte innovativer Arbeitspolitik: Good-practice-Beispiele aus dem Maschinenbau, der Automobil-, Elektro- und Chemischen Industrie“, Edition Sigma, Berlin, 2004.

[5] E. Appelbaum, and R. Batt, “The new American workplace: Transforming work systems in the United States," ILR Press, Ithaca, NY, 1994.

[6] E. Appelbaum, T. Bailey, P. Berg, "Manufacturing advantage. Why high-performance work systems pay off," Ithaca, NY: Cornell Univ. Press, 2000.

[7] K. Denton, "High performance work systems: the sum really is greater than its parts," Measuring Business Excellence 10(4), 2006, pp. 4-7. http://dx.doi.org/10.1108/13683040610719236

[8] P. Boxall, and K. Macky, "Research and theory on highperformance work systems: progressing the high-involvement stream,” in Human Resource Management Journal 19(1), 2009, pp. 3-23. http://dx.doi.org/10.1111/j.1748-8583.2008.00082.x

[9] C. L. O’ Regan, “The Impact of High Performance Work Systems on Innovation Performance: A Study of Irish Companies,” Master Thesis, Dublin City University, 2011.

[10] P. Totterdill, P. "New forms of work organisation: the high road to innovation”, in Enterprise for Health Management Conference, London, 30-31 October 2008.

[11] I. Nonaka, and H. Takeuchi, “The Knowledge Creating Company: How Japanese Companies Create the Dynamics of Innovation," Oxford University Press, Oxford, 1995.

[12] L. Prusak, "Where Did Knowledge Management Come From?," 2001, http://www.research.ibm.com:80/journal/sj/404/prusak.html, accessed 30.11.2008.

[13] M. Polanyi, “The Tacit Dimension, Smith,” Gloucester, 1966. 
[14] V. Allee, "The Future of Knowledge: Increasing Prosperity through Value Networks,” Butterworth Heinemann, Amsterdam, 2003.

[15] D.G. Andriessen, "Stuff or Love? How Metaphors Direct Our Efforts to Manage Knowledge in Organizations", in Knowledge Management Research \& Practice, Vol. 6, 2008, pp. 5-12, http://www.palgrave-

journals.com/kmrp/journal/v6/n1/full/8500169a.html, accessed 28.3.2010.

[16] J.S Brown, and P. Duguid, "The Social Life of Information," Harvard Business School Press, Boston, 2000.

[17] E. Gatarik, and R. Born, R., „Sharing Expertise als Kern von Wissensmanagement,“ Springer Gabler, Wiesbaden, 2012. http://dx.doi.org/10.1007/978-3-8349-7157-9

[18] P. H. Christensen, "Knowledge sharing: moving away from the obsession with best practices", Journal of Knowledge Management, Vol. 11 Iss: 1, 2007, pp. 36-47. http://dx.doi.org/ 10.1108/13673270710728222

[19] T. Proença, "Self-managed work teams: an enabling or coercive nature," The International Journal of Human Resource Management, Vol. 21, No. 3, February 2010, p. 383. http://dx.doi.org/10.1080/09585190903546870
[20] D. H. Pink, "Drive: The Surprising Truth About What Motivates Us,” First Riverhead trade pbk. edition ,Riverhead Books, New York, NY:, 2011.

[21] F. van Eijnatten, M. Kira, and T. Backström, "Creating Sustainable Work Systems Developing Social Sustainability," edited by J. Forslin, P. Docherty, and A . B . (Rami) Shani, Routledge, 2002.

[22] F. van Eijnatten, "Chaos and Complexity, An Overview of the 'New Science," in Organization and Management, Review Sciences De Gestion, Vol. 40, 2004.

[23] St-Germain, M. (2010). The Results-Oriented Organisations: a Critical Look from a Bertalanffyan Perspective. In BCSSS Lectures “Uncommon Sense in Thinking Society". Vienna, 10 December, 2010.

\section{AUTHORS}

Thomas Wallner and Martin Menrad are with Logistikum, University of Applied Sciences Upper Austria, Steyr, Austria.

Received 24 October 2012. Published as resubmitted by the authors 14 November 2012 